This is the peer reviewed version of the following article: Synlett, 2016,27, 2761, which has been published in final form at https://www.thieme-connect.de/products/ejournals/abstract/10.1055/s-0036-1589409 copyright oGeorg Thieme Verlag Stuttgart·New York

\title{
Benziodoxol(on)es Reagents as Tools in Organic Synthesis: Backgrounds of Discovery at the Laboratory of Catalysis and Organic Synthesis
}

\section{Jerome Waser*a}

a Laboratory of Catalysis and Organic Synthesis, Ecole Polytechnique Fédérale de Lausanne, EPFL SB ISIC LCSO, BCH 4306, 1015 Lausanne, Switzerland.

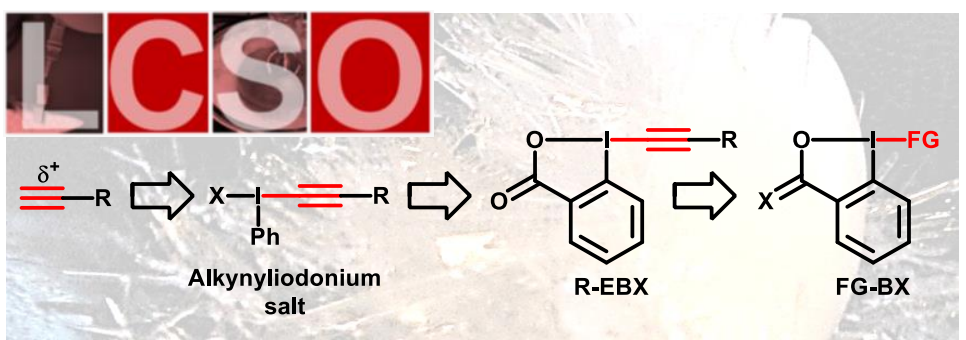

\begin{abstract}
Received:
Published online:

Abstract In this review, a personal account of our work in the field of hypervalent iodine reagents is presented. Pioneering experiments, which led to the discovery of the exceptional reactivity of EthynylBenziodoXol(on)e (EBX) reagents as electrophilic alkyne synthons is first discussed, including the alkynylation of ketoesters, olefins and heterocycles. Our further work involving EBX reagents in domino reactions and the alkynylation of thiols, as well as the use of benziodoxole reagents for azidation reactions is then described. Finally, the most recent results involving radicals and carbenes as reaction partners for EBX reagents and their first use in chemical biology are presented. The purpose of this review is not to give an extensive overview of our results, but to show the "true story" beyond the discovery by presenting the most important pioneering experiments. Failed attempts and near misses are also shortly discussed.
\end{abstract}

Key words Hypervalent lodine, Alkynes, EBX, Azides, Heterocycles, Synthetic Methods

\section{Table of Content:}

1. Introduction

2. First Use of EBX reagents

3. Discovering new reactions with benziodoxole reagents

4. New partners for EBX reagents

5. Going beyond synthetic organic chemistry

6. Conclusion

\section{Introduction}

Hypervalent iodine reagents have long been considered as bonding curiosities, of interest only for specialists. But the hypervalent bond combining 4 electrons on three atoms is not only interesting from the theoretical point of view, it also confers an exceptional reactivity to these reagents, allowing them to emulate more toxic and expansive late transition metals. ${ }^{1}$ The main synthetic community became more aware of this potential following the discovery and broad use of the DessMartin periodinane (1) as a mild oxidant (Figure 1). ${ }^{2}$ Nowadays, hypervalent iodine reagents, both in the III and V oxidation states, are broadly used in organic synthesis. ${ }^{1}$
The success of the Dess-Martin reagent (1) is due to its right balance between reactivity and stability, which is originating from its cyclic structure. The enhanced stability of heterocyclic hypervalent iodine reagents, especially benziodoxolones derived from 2-iodobenzoic acid, is indeed well-established, and has allowed the isolation of unique reagents, such as trifluoromethyl (Togni reagents $\mathbf{2}$ and 3 ) or azido derivatives (benziodoxolone 4). ${ }^{3}$<smiles>CC(=O)O[Te]1(OC(C)=O)(OC(C)=O)OC(=O)c2ccccc21</smiles>

Dess-Martin periodinane<smiles>O=C1OI(C(F)(F)F)c2ccccc21</smiles>

Togni Reagents<smiles>N[I-]1(N)OC(=O)c2ccccc21</smiles>

$\mathrm{ABX}$<smiles>[R]C#CI1COC(=O)c2ccccc21</smiles>

R-EBX

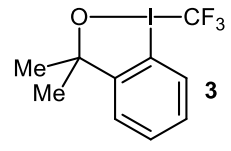<smiles>N#CI1OC(=O)c2ccccc21</smiles>

CBX
Figure 1: Selected examples of cyclic hypervalent iodine reagents.

Surprisingly, the potential of cyclic hypervalent iodine reagents for functional group transfer has been long neglected, probably because their enhanced stability is normally accompanied by diminished reactivity. However, in cases where decomposition of the reagent is an issue, for example in presence of bases or metal catalysts, cyclic hypervalent iodine reagents can be uniquely successful. This was amply demonstrated by Togni and co-workers, who introduced trifluoromethyl benziodoxol(on)es $\mathbf{2}$ and $\mathbf{3}$ as efficient $\mathrm{CF}_{3}{ }^{+}$synthon in many transformations. ${ }^{4}$ They were soon followed by other researchers around the world. ${ }^{5}$ Our group on the other hand became interested in the transfer of alkynes using EthynylBenziodoXolone (EBX, 5) reagents, first introduced by the groups of Ochiai and Zhdankin, ${ }^{6}$ with the goal of developing a more general electrophilic acetylene synthon. The concept was then extended to the transfer of other inherently nucleophilic groups, such as azides and nitriles (benziodoxolones $\mathbf{4}$ and 6). Herein, a personal account of our work in the area is given. The purpose of this 
review is not to give an extensive overview of our results, which has already been done in several other publications, ${ }^{7}$ but to show the "true story" beyond the discovery by presenting the most important pioneering experiments. Failed attempts and near misses will also be shortly discussed.

\section{First uses of EBX reagents}

Alkynes are among the most versatile functional groups in synthetic chemistry, and are also highly useful in chemical biology and materials science. ${ }^{8}$ It is therefore not surprising that many research groups in fundamental organic chemistry have focused on the development of new alkynylation reactions. In 2006, I was well aware of this fact, after a PhD in the Carreira group and a postdoc in the Trost group, which are well known for their innovative research involving the synthesis and use of alkynes. ${ }^{9}$ Nevertheless, the introduction of alkynes into molecules was mostly based on the addition of acetylides onto electrophiles. I wondered if a general electrophilic acetylene synthon could be developed, in order to functionalize the myriad of nucleophiles present in organic molecules. Of course, others had already worked on the same idea and alkynyl halogens, sulfones, high-valent lead compounds and iodonium salts had been used for this purpose. ${ }^{7 b}$ Nevertheless, halogens and sulfones often presented limited reactivity, whereas lead compounds were unstable and highly toxic. Alkynyliodonium salts on the other hand appeared as the right combination of reactivity and stability. ${ }^{10}$ After pioneering works by Beringer, ${ }^{11}$ they had indeed be used successfully by the groups of Ochiai and Stang in the alkynylation of ketoesters, heteroatoms and organometallic intermediates between 1985 and 1995.12 Nevertheless, research in the area began to decline after 1995. In 2006, I wondered if these reagents could be successfully used in modern (asymmetric) catalysis and I based one of my research proposals on this idea when applying for academic positions in Fall 2006 (Scheme 1).13 The original plan was to investigate three transformations: 1) the alkynylation of $\mathrm{C}-\mathrm{H}$ bonds using metal-catalysis and either a directing group or the innate reactivity of the $\mathrm{C}-\mathrm{H}$ bond, 2) the asymmetric synthesis of quaternary propargylic centers using chiral catalysts and 3) the development of an oxyalkynylation of double bonds based on an interrupted Wacker process with palladium catalysts.

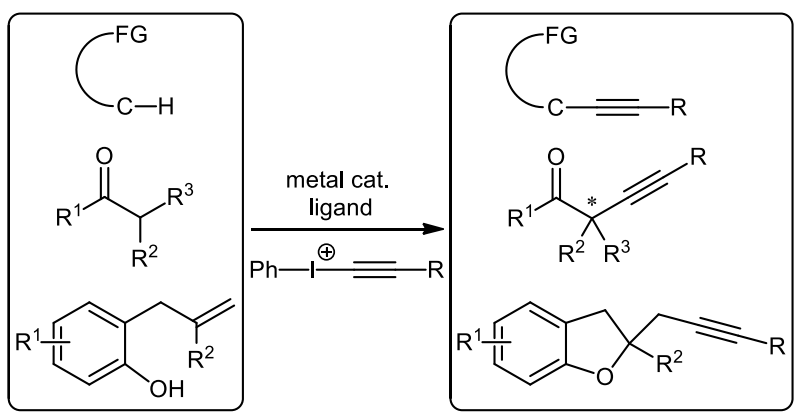

Scheme 1: Original research proposal abstract for electrophilic alkynylation using hypervalent iodine reagents (10.2006).

This three projects where based on the naïve assumption that alkynyliodonium salts will act as general electrophilic acetylene synthons, which will prove incorrect later. Nevertheless, we were really pleased to be able to realize all these three projects in the following years, partly with luck, partly through design.
In October 2007, my first PhD student, Ms. Davinia Fernandez Gonzalez, started to work on this project. We decided to focus first on the asymmetric alkynylation of ketoesters, as this transformation has already been realized in a racemic way and it looked "easier" for a start. Indeed, Ochiai and co-workers had demonstrated that silylalkynyl iodonium salts cleanly give the alkynes products, whereas aliphatic derivatives gave $\mathrm{C}-\mathrm{H}$ insertion reactions.12a,b We therefore decided to use silylalkynyliodonium salts and were first able to reproduce Ochiai's results using stoichiometric deprotonation of the ketoester with a strong base. A first important proof of concept was realized when we could use $10 \mathrm{~mol} \%$ of cinchona-derived phase transfer catalyst 8 to promote the alkynylation of ketoester 7 in 67\% yield (Scheme 2, A). Our choice of phasetransfer catalyst 8 was based on the excellent results obtained by Jørgensen and co-workers in the only so far reported enantioselective alkynylation of keto-esters, unfortunately limited to propiolic acid derivatives. ${ }^{14}$ However, no significant enantioselectivity could be measured in this case, and extensive investigations of the reaction conditions and catalyst structure were not successful.

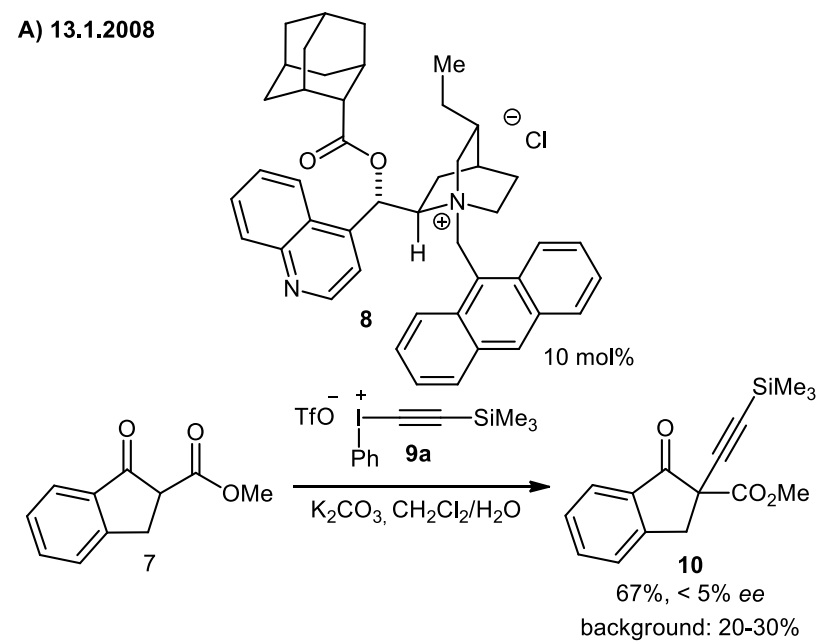

B) 2.4.2008

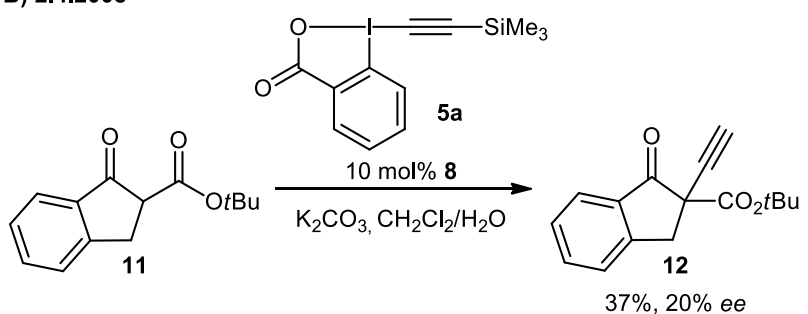

Scheme 2: Alkynylation of ketoesters under phase-transfer conditions.

We observed that $20-30 \%$ product $\mathbf{1 0}$ was still formed in the absence of catalyst, and wondered therefore how we could diminish the reactivity of the reagent. One possibility would be to replace triflate in the alkynyliodonium salt by a more coordinating anion such as acetate. However, such salts are unstable, as carboxylates react with alkynyliodonium salts to give highly reactive ynoate esters. ${ }^{15}$ By screening the literature, we became for the first time aware of the existence of ethynyl benziodoxolones derived from iodobenzoic acids, first synthesized by Ochiai and co-workers and later investigated by Zhdankin and co-workers. ${ }^{6}$ By incorporating the iodine atom 
into a heterocyclic structure, these reagents are now perfectly stable. In fact, we were pleased to see that the background reaction was slower with this class of reagents and observed for the first time a measurable enantioselectivity (20\%) using TMSEBX (5a) for the alkynylation of ketoester 11 (Scheme 2, B). Interestingly, the silyl group was very labile on ethynylbenziodoxolone reagents and free alkyne $\mathbf{1 2}$ was directly obtained. In the following two years, numerous attempts were made to develop an efficient enantioselective transformation, but the enantioselectivity remained below $50 \%$. In particular, attempts to use a more sterically hindered triisopropyl silyl group onto the alkyne did not lead to any improvement in enantioselectivity. Nevertheless, a highly efficient non enantioselective alkynylation could be developed using TBAF both as base and activator, and the scope of the reaction could be significantly extended. ${ }^{16}$ In 2011, we were able to increase the enantioselectivity to $79 \%$ using Maruoka's phase transfer catalyst, at which point investigations into this transformation were discontinued. ${ }^{17}$ Intensive attempts to use other type of catalysts, such as Cu-BOX, Ti-Taddol, chiral urea, bifunctional urea and amines with keto-esters or chiral enamines generated in situ from aldehydes ${ }^{18}$ were not successful.

In October 2008, as Ms. Fernandez Gonzalez was still working on the asymmetric alkynylation of ketoesters, Mr. Stéphane Erard started his master work on the second project, the oxyalkynylation of olefins, under her supervision. At this point, both alkynyliodonium and ethynylbenziodoxolones were available in the group. During the four months of the master work, interesting preliminary results were obtained (Scheme 3, A). A proof of concept was first realized using a palladium salt and alkynyliodonium 9a. The desired product 14a was obtained in $6 \%$ yield. Most of alkynyliodonium salt 9a was converted to dimer 15, however. Because they were available in the group, we then tested the benziodoxolones $\mathbf{5 a}$ and $\mathbf{5 b}$. Although silyl transfer to give $\mathbf{1 6}$ was favored with TMS-EBX (5a), TIPS-EBX (5b) gave the oxyalkynylation product $\mathbf{1 4 b}$ in $26 \%$ yield. The cyclic nature of the reagent was essential for success, as no increase in yield was observed when using a triisopropylsilyl derived alkynyl iodonium salt. In retrospect, it was pure luck that a reagent we had first used to improve the enantioselectivity in a phase-transfer reaction gave also superior results in a palladium-catalyzed transformation. In 2009, Mr. Stefano Nicolai, a new PhD student, started to work on the project and could quickly improve the yield to $73 \%$ by using palladium hexafluoroacetonate as catalyst (Scheme 3, B). The reaction was successful both in case of phenols and carboxylic acids as nucleophiles. ${ }^{19}$ Later it could be also extended to nitrogen nucleophiles and applied to the total synthesis of alkaloid natural products. ${ }^{20}$
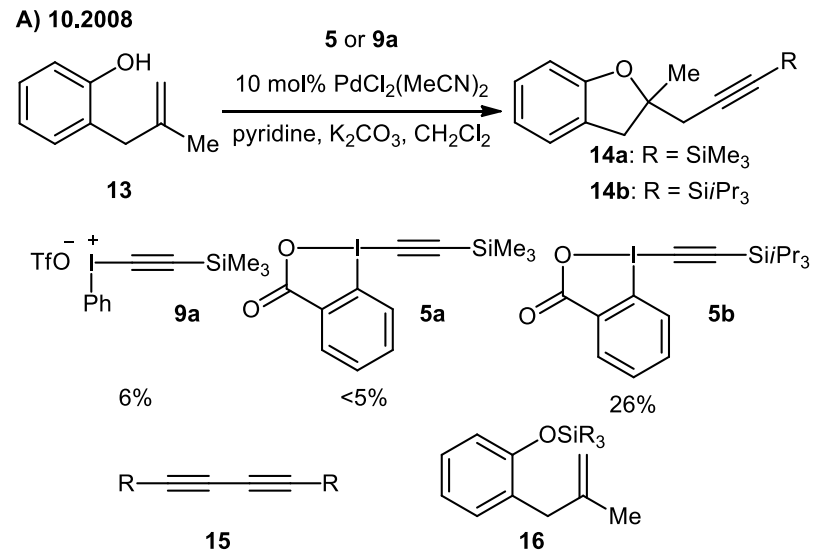

B) 1.2009

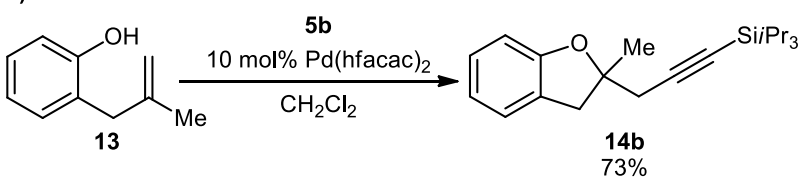

Scheme 3: Oxyalkynylation of olefins.

With the first catalytic process involving ethynylbenziodoxolones in our hands, it became clear to us that this class of reagents had a high synthetic potential. At the same time, a second project running in the group based on the use of mixed urea-carbene as organocatalysts was not giving satisfying results. ${ }^{21}$ We therefore took the decision to "kill" this project and move a further PhD student, Mr. Jonathan Brand to the hypervalent iodine team to investigate the challenging $\mathrm{C}-\mathrm{H}$ alkynylation of heterocycles. Inspired by the pioneering works of Sanford and Gaunt on the arylation of indoles with aryliodonium salts, ${ }^{22}$ we decided to investigate electron-rich heterocycles first. Preliminary results involving established copper and palladium catalysts were disappointing, but nevertheless again pointed at the superiority of benziodoxolone reagents over alkynyliodonium salts: a small amount (around $5 \%$ ) of C2-alkynylated indole $\mathbf{1 8 a}$ could be obtained with palladium(II) acetate as catalyst only when using TIPS-EBX (5b) (Scheme 4, A). We therefore extended the search to other type of catalysts and found that $\mathrm{AuCl}$ was uniquely able to activated TIPS-EBX (5b) for the C3-alkynylation of indole (17). Rapidly, the reaction could be optimized to give excellent yields for both indoles and pyrroles (Scheme 4, B). ${ }^{23}$ As the needed heterocycle substrates were commercially available, a few months were enough to investigate the scope of the reaction and send a publication in September 2009. Consequently, this third project we had started using hypervalent iodine reagents ended up to be the first one published, whereas our original work on ketoesters appeared only nearly one year later. ${ }^{16}$ It is in the latter publication that we introduced for the first time the abbreviation EBX (for EthynylBenziodoXol(on)e), which is now broadly used. 


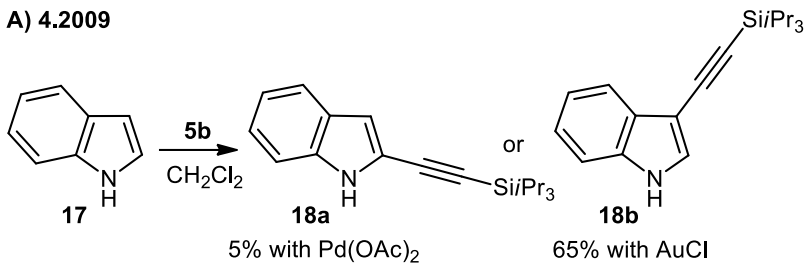

B) 9.2009

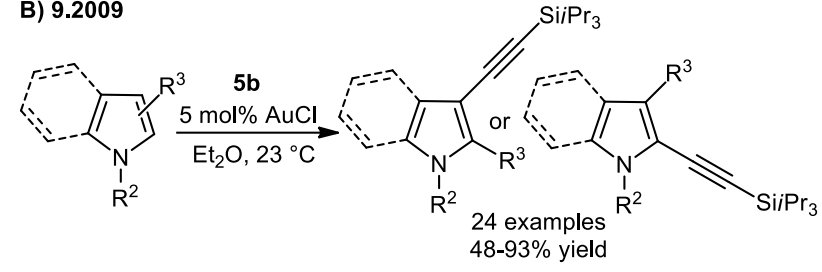

Scheme 4: Alkynylation of indoles and pyrroles.

During the following years, our group was able to extend the scope of the gold-catalyzed reaction to other electron-rich heterocycles, such as thiophenes, anilines, furans and benzofurans. ${ }^{24}$ This was the occasion to learn more about TIPSEBX and to become aware of its exceptional properties, such as:

- High stability under many reaction conditions (including isopropanol at $60^{\circ} \mathrm{C}$ !)

- $\quad$ Easily reproducible synthesis on larger scale (up to 40 g) 25

- Further modulation of the reactivity possible via structural changes or by the use of additives.

The later point is probably one of the main advantages of benziodoxole reagents in general: the "ligand-sphere" around the iodine atom can be finely modulated to change its reactivity, like it would be the case for an organometallic reagent (Figure 2). Benziodoxole reagents were less reactive: the hexafluoroisopropyl derivatives $\mathbf{1 9}$ reported by Zhdankin gave only low yields, whereas the new dimethyl benziodoxole $\mathbf{2 0}$ gave no product at all. Not surprisingly, electron-deficient EBX 5c reacted faster. Less obvious was the higher reactivity of ortho-substituted EBX 5d and 5e. For the former, a twist of the hypervalent bond out of linearity was observed which could explain the higher reactivity, but no good explanation could be found for the latter. From the numerous synthesized EBX reagents, none was better than the original TIPS-EBX (5b). Nevertheless, these broad studies were certainly not a waste of time, as reagent 19 would be crucial to develop domino reactions later (see section 3 ), and reagent $\mathbf{5 e}$ would be used by Nachtsheim and co-workers in rhodium-catalyzed reactions (under the short-name TIPS-EBX*). ${ }^{26}$ On the other hand, the activation of TIPS-EBX (5b) with either TFA or zinc triflate was highly successful for the alkynylation of less reactive heterocycles. ${ }^{24}$ The formation of activated adducts $\mathbf{5 f}$ and $\mathbf{5 g}$ can clearly see by shifts of the NMR signals. These compounds displayed enhanced reactivity, but are still more stable than alkynyliodonium salts, which decomposed under the reaction conditions.

The alkynylation reaction of heterocycles was a highly successful reaction, but it still displayed severe limitations:
- It was limited to the transfer of silyl alkynes

- Only sufficiently electron-rich positions can be alkynylated

- The mechanism of the reaction was poorly understood.

For the last point in particular, we were not able to isolate any relevant gold intermediates, as electron-donating ligands immediately shut-down the reaction. Therefore, we could not determine if the reaction was proceeding via an addition elimination mechanism, of via a redox mechanism involving gold(III) intermediates. In 2014, Ariafard also suggested that a gold-iodine alkyne exchange mechanism would be possible based on computational studies. ${ }^{27}$

\section{Discovering new reactions with benziodoxole reagents}

At the end of 2010, our three projects on hypervalent iodine reagents were well ongoing, and it became clear that we had more by luck than design stumbled upon the exceptional properties of EBX reagents. When considering that one of the most useful reaction of alkynes is the [3+2] cycloaddition with azides, considered as the paramount of "Click chemistry" 28 and that Zhandkin and co-workers and Kita and co-workers have reported the synthesis and use of corresponding azidobenziodoxole reagents such as ABX (4), ${ }^{29}$ the functionalization of $\mathrm{C}-\mathrm{H}$ bonds using both EBX and azido-benziodoxole reagents appeared particularly attractive. We indeed had preliminary results for the $\mathrm{C}-\mathrm{H}$ alkynylation of indoles on tryptophan derivatives using a gold catalyst already in $2010 .{ }^{30}$ Our original plan was based on three approaches:

- $\quad$ C-H functionalization using directing groups and late transition metal catalysts

- $\quad \mathrm{C}-\mathrm{H}$ functionalization of $\mathrm{SP}^{3} \mathrm{C}-\mathrm{H}$ bonds using copper and iron catalysts

- Functionalization of radical intermediates.

Unfortunately, a grant application for this project was rejected. With limited resources, we needed to re-focus our research. We decided therefore to concentrate only on unknown alkynylation processes and generate preliminary results on azidation reactions. In particular, we choose not to work on the directing group mediated $\mathrm{C}-\mathrm{H}$ alkynylation using transition metals, as this transformation can be realized with alkynyl bromides ${ }^{31}$ and on the alkynylation of radicals, which can be performed with alkynyl sulfones. ${ }^{32}$ Interestingly, both transformations were later realized by other research groups using EBX reagents. ${ }^{33}$

With EBX reagents, we decided to start with two goals: the synthesis of heterocycles alkynylated on other positions than the most electron-rich one and the formation of $\mathrm{C}-\mathrm{X}$ bonds instead of $\mathrm{C}-\mathrm{C}$ bonds. For the former, the use of $\mathrm{C}-\mathrm{H}$ functionalization methods is limited if one wants to avoid directing groups. For example, Mr. Gergely Tolnai and Ms Stephanie Ganss in our group were able to optimize the C2alkynylation of indoles using a palladium catalyst, ${ }^{34}$ but functionalization of the arene ring cannot be achieved. We therefore considered generating a reactive intermediate in situ using a cyclization reaction. 


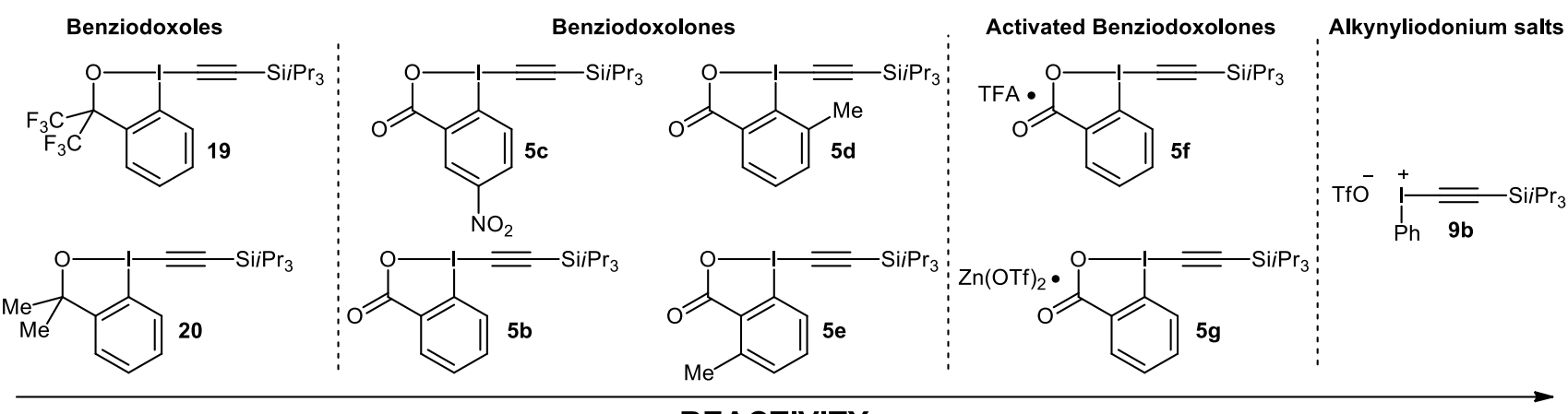

\section{REACTIVITY}

Figure 2: Modulating the reactivity of EBX reagents in the gold-catalyzed alkynylation of (hetero)arenes.

Mr. Jonathan Brand made a first attempt using ortho-alkynyl aniline $\mathbf{2 1}$ as substrate in 2010 (Scheme 5). ${ }^{35}$ This early work showed the challenge inherent to the approach: The catalyst properties required for the cyclization and the alkynylation steps are different, making it difficult to find a single metal complex able to promote the complete domino process. Indeed, in this case $\mathrm{AuCl}$ did not lead to a clean cyclization (Scheme 5, A), whereas gold(III) catalysts such as $\mathrm{NaAuCl}_{4}$ promoted cyclization, but not alkynylation (Scheme 5, B). Only a one-pot process could be realized, requiring two different catalysts and full completion of the cyclization step had to be reached before performing alkynylation (Scheme 5, C). This approach only allowed the synthesis of the same alkynylated heterocycles as obtained by $\mathrm{C}-\mathrm{H}$ functionalization, and was therefore not really attractive.

In 2012, a new PhD student, Mr. Yifan Li, re-investigated this approach on a different transformation: the gold-catalyzed cyclization of ketoallenes developed by Hashmi and co-workers (Scheme 6, A). ${ }^{36}$ This transformation is particularly interesting, because the gold organometallic intermediate is formed in C3 position, whereas direct $\mathrm{C}$ - $\mathrm{H}$ alkynylation proceeds in $\mathrm{C}$ 2.<smiles>Nc1ccccc1C#CC#Cc1ccccc1N</smiles>

$$
\underset{\text { TIPS-EBX }(\mathbf{5 b})}{\stackrel{\text { AuCl cat. }}{\longrightarrow}} \text { no cyclization }
$$

$$
\underset{\text { TIPS-EBX }(\mathbf{5 b})}{\stackrel{\mathrm{NaAuCl}}{4} \text { cat. }}
$$<smiles>c1ccc(-c2cc3ccccc3[nH]2)cc1</smiles><smiles>Nc1ccccc1C#CPc1ccccc1</smiles>

$$
\begin{aligned}
& \text { 1) } \mathrm{NaAuCl}_{4} \text { cat. } \\
& \text { 2) } \mathrm{AuCl} \text { cat. }
\end{aligned}
$$
TIPS-EBX (5b)<smiles>CC(C)[AsH2]C#Cc1c(-c2ccccc2)[nH]c2ccccc12</smiles>

Scheme 5: First attempts towards a domino cyclizationalkynylation reaction.

As we knew that the alkynylation reaction is promoted by $\mathrm{Au}(\mathrm{I})$ only, we logically focused first on this type of catalysts. However, we were never able to observe the desired product. It is only when we extended the investigation to $\mathrm{Au}(\mathrm{III})$ catalyst 25 that we were able to isolate the desired C3-alkynylation product $\mathbf{2 6}$ in $24 \%$ yield starting from allene $\mathbf{2 4}$, together with
7\% of C2-alkynylation product $\mathbf{2 7}$ (Scheme 6, B). The picolinic acid ligand was essential for the success of the reaction. With this result, a question immediately arose: Is the C3-alkynylation product really formed during a domino process, or is the observed product mixture just obtained due to low selectivity in an eventual C-H alkynylation step?

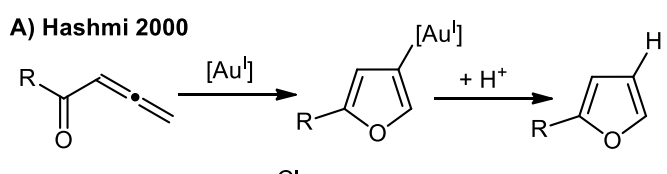

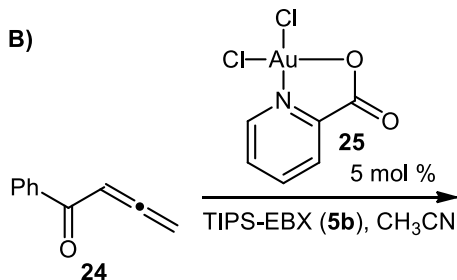<smiles>CCCCCC[o+]1cc(C#C[SiH2]CCCC)cc1-c1ccc(-c2ccccc2)o1</smiles>

C)<smiles>c1coc(-c2ccco2)c1</smiles>

$5 \mathrm{~mol} \% 25$

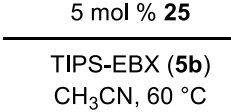

D)

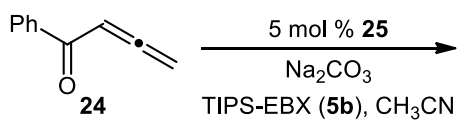

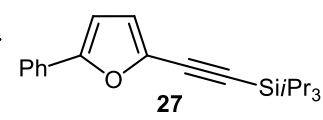

28 $\mathrm{TIPS}-\mathrm{EBX}(5 \mathbf{b})$
$\mathrm{CH}_{3} \mathrm{CN}, 60^{\circ} \mathrm{C}$ $3 \%$
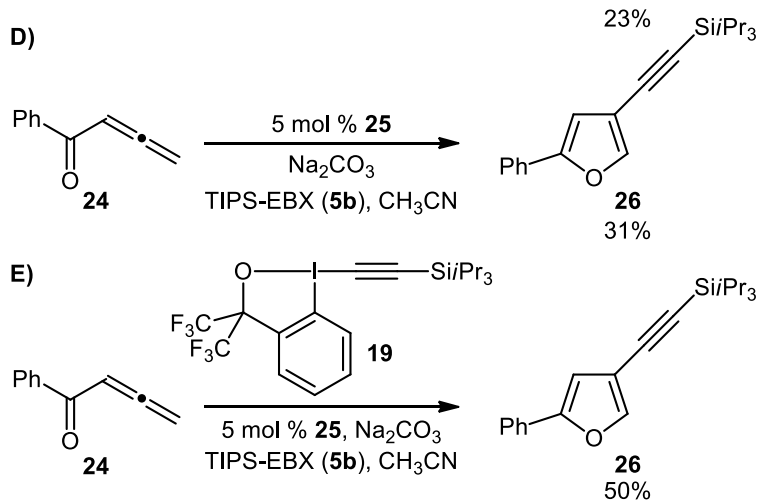

Scheme 6: First domino cyclization-alkynylation process.

When a control experiment was done using 2-phenyl furan (28) as substrate under slightly forcing conditions (heating to $60^{\circ} \mathrm{C}$ ), only C2 alkynylation product $\mathbf{2 7}$ was observed (Scheme 6, C). This experiment indicated that the two observed products were indeed coming from mechanistically different processes. Phenyl-furan $\mathbf{2 8}$ probably resulted from protonation of the formed organogold intermediate. Indeed, when sodium bicarbonate was added to the reaction mixture, only the C3 alkynylation product $\mathbf{2 6}$ was observed (Scheme 6, D). 
Nevertheless, we were unable to further improve the yield using TIPS-EBX (5b) as reagent. It is at this point that our earlier studied on systematic modification of EBX reagents finally paid off: Bis(trifluoromethyl) benziodoxole 19 led to an increase of the yield to $50 \%$, and further fine tuning of the reaction conditions with this reagent finally led to formation of $\mathbf{2 6}$ in $68 \%$ yield. ${ }^{37}$ The reaction proceeded especially well with electron-rich aryl and alkyl substituents on the ketone and could be used for the synthesis of multi-substituted furans.

The next important question to answer in this project was about the generality of the approach: Could other domino cyclizationalkynylation processes be developed? We decided to attempt the domino process based on another cyclization process developed by Hashmi and co-workers: the intramolecular reaction of pyrroles with alkynes to give indoles (Scheme 7 , A). ${ }^{38}$ However, numerous attempts using gold catalysts were unsuccessful. In this case, platinum chloride was discovered as the best catalyst (Scheme 7, B). ${ }^{39}$ Using methanol as a leaving group, the desired domino cyclization alkynylation product $\mathbf{3 0}$ could be obtained in $91 \%$ yield. Again, this project was not without surprise: Based on the mechanism of the cyclization reaction of Hashmi involving $\mathrm{C} 2$ attack and 1,2-shift of the alkoxy substituent (Scheme 7, A), we were expecting to obtain the C6-alkynylation product. However, careful NMR analysis as well as an independent synthesis from the corresponding aryl bromide showed that the formed product $\mathbf{3 0}$ was in fact $\mathrm{C} 5$ alkynylated! The only speculative explanation we have so far is that the platinum atom is better able to stabilized positive charges, therefore promoting shift of the other alkyl group in the 1,2-migration step. This unexpected result was synthetically useful, as it allowed us to gain access to C5-alkynylated products, whereas C6-alkynylated indoles could also be synthesized just by using C3-substituted pyrroles as starting materials.

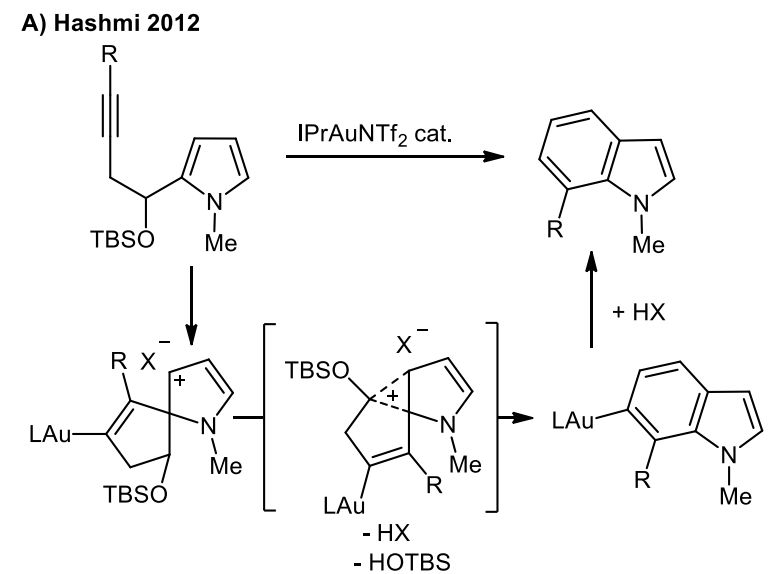

B)

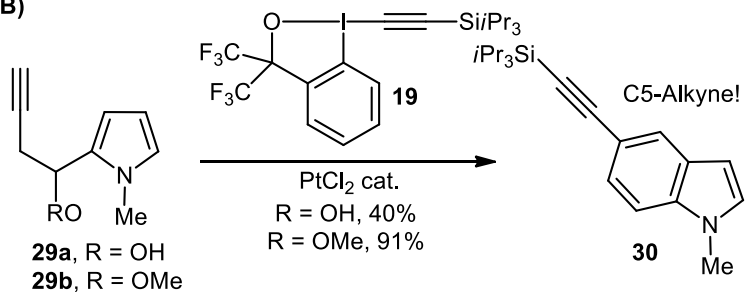

Scheme 7: Domino process for the synthesis of arenealkynylated indoles.
In parallel to our work on domino reactions, we decided to investigate for the first time the formation of $\mathrm{C}-\mathrm{X}$ bonds with EBX reagents. As several methods were already reported for the synthesis of ynamides, ${ }^{40}$ we decided to focus on the formation of $\mathrm{C}-\mathrm{O}$ and $\mathrm{C}-\mathrm{S}$ bonds. Although we were never able to develop an efficient method for the synthesis of ynol ethers, the synthesis of thioalkynes was indeed highly successful.

When considering that thiolates are among the best nucleophiles existing in organic chemistry, it is surprising that reports on the use of alkynyliodonium salts to realize C-S bond formation were scarce prior to $2012 .{ }^{41}$ When Dr. Reto Frei in our group first attempted the alkynylation of benzyl thiol (31) with alkynyliodonium salt $\mathbf{9 b}$, the reason became clear: Reagent 9b is also a strong oxidant leading to a fast oxidation to the disulfide 33, with only traces of alkynylation product 32a (Scheme 8, A). Fortunately, the oxidation was slower with EBX reagents, and if tetramethylguanidine was used as a base with TIPS-EBX (5b), quantitative formation of thioalkyne 32a was observed (Scheme 8, B). ${ }^{42}$ We became aware then that we had one very rare "dream reaction" for organic chemists: the thiol alkynylation was quantitative, very clean and finished in less than one minute in an open flask at room temperature!

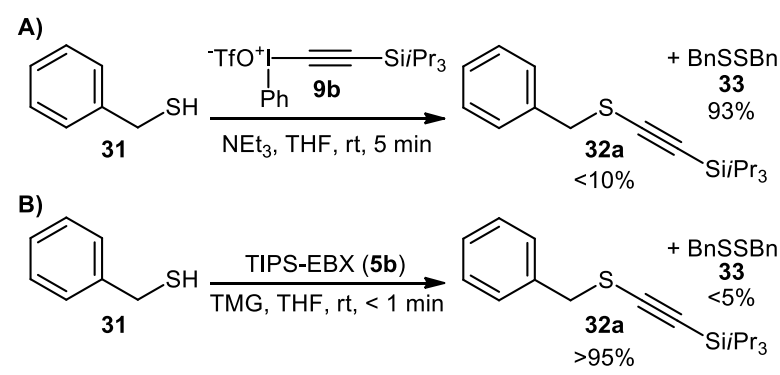

Scheme 8: Alkynylation of thiols.

Whereas performing the reaction was fast, understanding the reasons for this exceptional rate took much more time. Our first speculative mechanism was based on Ochiai's mechanism for the reaction of nucleophiles with alkynyliodonium salts: conjugate addition, followed by $\alpha$-elimination and 1,2-shift (Scheme 9, A). ${ }^{12 a}$ We sought to slow down the 1,2-shift by using Me-EBX as reagent, and indeed we were able to isolate vinylbenziodoxolone $\mathbf{3 4}$ resulting from the protonation of the expected intermediate, albeit only in low yield as the alkynylation product was still formed preferentially. At this point, Dr. Matt Wodrich performed computations on the reaction mechanism leading to a completely unexpected result (Scheme 9, B): instead of the expected conjugated addition pathway via transition state I, a new unprecedented three-atom concerted transition state II with direct C-S bond formation on the $\alpha$ atom was predicted to be much lower in energy.43 Although it better explained the reaction rate, it was difficult to rationalize the isolation of vinyl benziodoxolone $\mathbf{3 4}$ with this mechanism. More in-depth computations allowed finally to identify a third mechanism: a four-atom transition state III leading to direct transfer of sulfur to the $\beta$ carbon of the alkyne. ${ }^{44}$ This mechanism was favored for alkyl-EBX reagents, whereas both $\alpha$ - and $\beta$ - additions were very close in energy for silyl-EBX reagents. The later was confirmed by reaction with C13-labeled TIPS-EBX $\mathbf{5 h}$, which gave a mixture of products $\mathbf{3 2} \mathbf{b}$ and $\mathbf{3 2} \mathbf{b}^{\prime}$ resulting from both pathways (Scheme 9, C). 


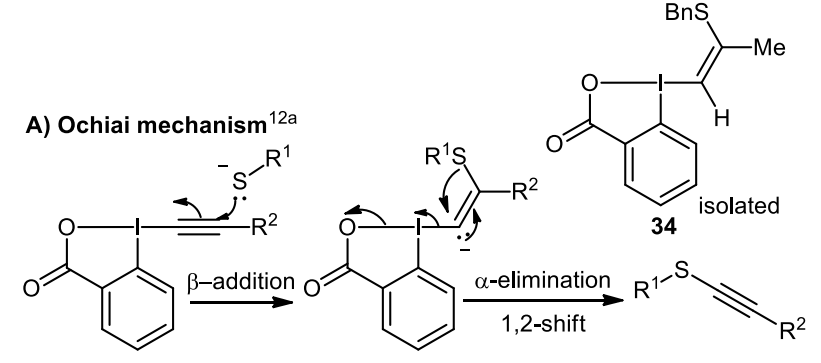

B) Refined transition states

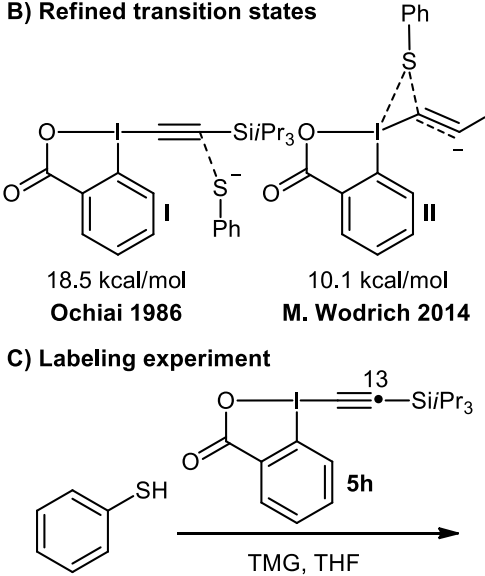

35

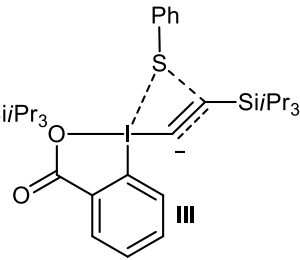

$9.3 \mathrm{kcal} / \mathrm{mol}$

M. Wodrich 2015

C) Labeling experiment

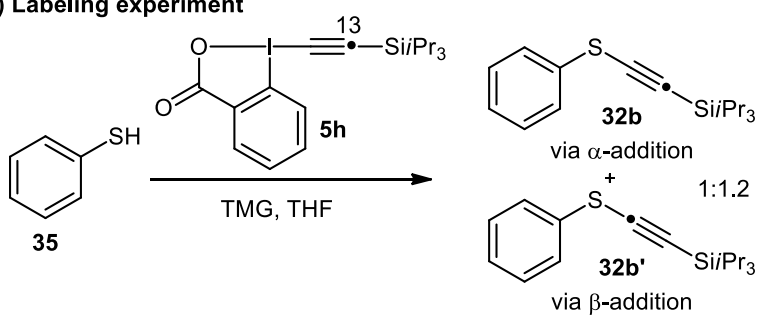

Scheme 9: Mechanism investigations on the alkynylation of thiols.<smiles>COc1ccc(CSC#CCCO)cc1</smiles>

32c, $93 \%$<smiles>ClCCCC#CSc1ccccc1Br</smiles>

$32 \mathrm{~g}, 87 \%$<smiles>CCOC(=O)C(CSC#CCCN)NC(=O)[C@H](Cc1c[nH]c2ccccc12)NC(=O)OCc1ccccc1</smiles>

$32 k, 60 \%$ 32d, $59 \%$<smiles>[SiH2]C#CSc1ccccc1Br</smiles>

32h, $97 \%$<smiles>CCOC(=O)C(CSC#Cc1c(C)cc(C)cc1C)NC(=O)[C@H](Cc1c[nH]c2ccccc12)NC(=O)OCc1ccccc1</smiles>

$321,80 \%$<smiles>Nc1cccc(SC#C[Pb])c1</smiles>

32e, $92 \%$<smiles>C[C@H](CSC#C[SiH2]C(C)(F)F)C(=O)N1CCC[C@H]1C(=O)O</smiles>

32i, $90 \%$<smiles>O=C(SC#C[AlH]C(F)(F)F)c1ccccc1</smiles>

$32 \mathrm{~m}, 94 \%$<smiles>O=[N+]([O-])C#CSc1nc2cc([18O][Na])ccc2[nH]1</smiles>

32f, $94 \%$<smiles>CCOC(=O)CSC#C[Sn+2]</smiles>

32j, $95 \%$

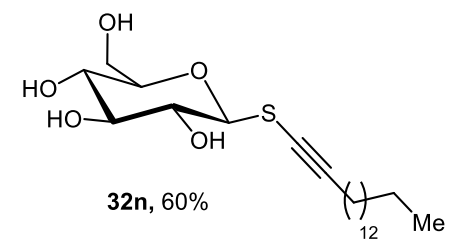<smiles>OCCCCCC#CSC#CCCCCCO</smiles><smiles>CC(C)(C#CSC#CC(C)(C)OCc1ccccc1)OCc1ccccc1</smiles>

$32 p, 74 \%$

Figure 3: Selected examples of thiol alkynylation products. 
In the meantime, we obtained a promising preliminary result on the azidation of ketoesters: azide $\mathbf{4 0}$ was obtained in $20 \%$ yield with ABX (4) from ketoester 11 (Scheme 10, B). We therefore decided to focus on this transformation. After optimization, the azidation of ketoesters gave excellent yields, and it could be extended to silyl enol ethers in the presence of a zinc catalyst (Scheme 10, C). ${ }^{49}$ For this transformation, we preferred to use reagent 41, which displayed a much lower tendency towards detonation as demonstrated by DSC measurements (Figure 4).50 Promising results were also obtained for asymmetric induction (up to $49 \%$ ee with a copper-Box catalyst), but these investigations were discontinued when Gade and co-workers reported a highly enantioselective azidation of ketoesters with reagent 41 using an iron catalyst. ${ }^{51}$ Instead, an indirect approach involving the enantioselective Tsuji-Trost allylation of racemic ethynyl, azido and cyano esters synthesized using the corresponding benziodoxole reagents could be developed. ${ }^{52}$

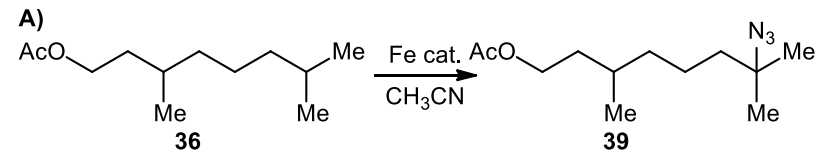

M. V. Vita, 9.2011: with 37: not observed Hartwig and Sharma, 2014: ${ }^{48}$ with $\mathrm{Fe}(\mathrm{OAc})_{2}, 38: 45 \%$<smiles>CC(C)C1COC(c2cccc(C3=NC(C(C)C)CO3)n2)=N1</smiles>

B) M. V. Vita, 9.2011<smiles>CCOC(=O)C1Cc2ccccc2C1=O</smiles><smiles>CCOC(=O)C1(N)Cc2ccccc2C1=O</smiles>

C) M. V. Vita, 2013

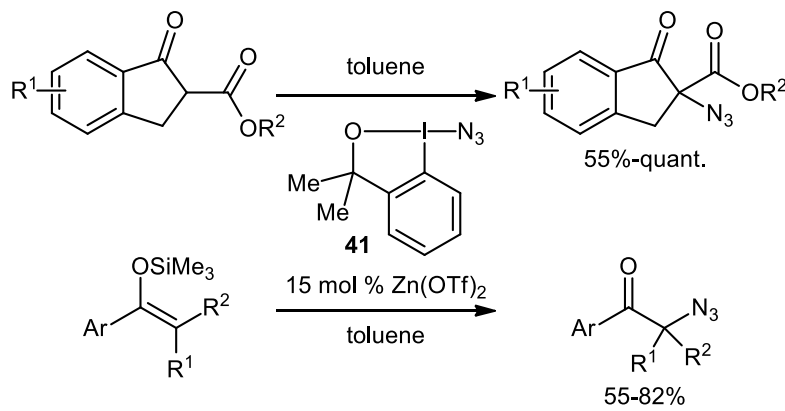

Scheme 10: Azidation with benziodoxole reagents.
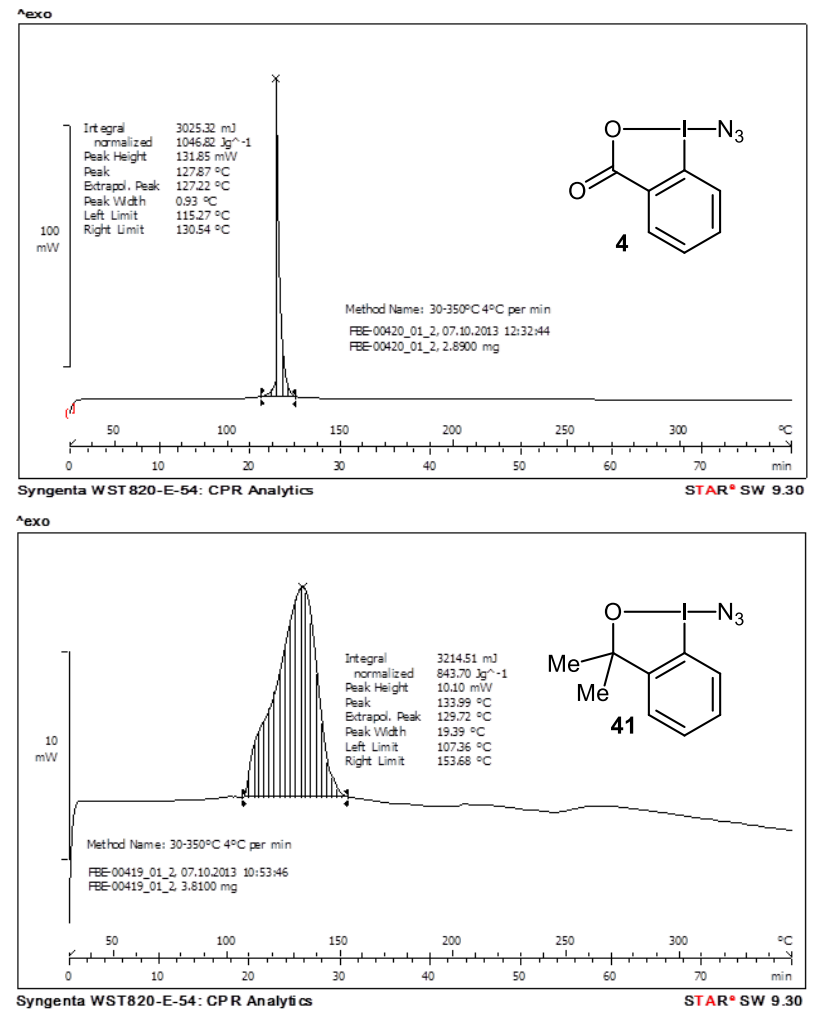

Figure 4: DSC profile of azido benziodoxoles $\mathbf{4}$ and $\mathbf{4 0}$

\section{New partners for EBX reagents}

Until 2014, we had focused mostly on the reaction of EBX reagents with nucleophiles, either heteroatoms or organometallic reagents. With now more resources available, we wanted to extend our investigations to other reactive intermediates, namely radicals and carbenes.

Concerning the former, we had wrongly assumed that the field of radical alkynylation was already sufficiently covered by the use of alkynyl sulfones. ${ }^{32}$ However, several groups had shown since 2012 that EBX can indeed be superior reagents for the alkynylation of radicals. ${ }^{33 \mathrm{~d}-\mathrm{f}}$ We were especially interested by the generation of radical using photoredox catalysts, as only visible light is needed and recent reports had shown that such conditions are compatible with EBX reagents. ${ }^{53}$ Carboxylic acids are interesting starting materials in this respect, because they are broadly available from the biomass and the generation of carbon centered radicals by decarboxylation under photoredox conditions is well established. ${ }^{54}$ Nevertheless, in 2014 no direct conversion of carboxylic acids to alkynes under photoredox conditions had been yet reported. After preliminary investigations by Dr. Thibaut Courant in 2014, a new PhD student, Mr. Franck Le Vaillant, started to work on this project. Not surprisingly, the classical $\mathrm{Ru}(\mathrm{bpy})_{3}$ catalyst $\mathbf{4 4}$ did not promote the decarboxylative alknylation of protected proline $\mathbf{4 2}$ (Scheme 11). It is known that an oxidation potential higher than $+0.95 \mathrm{~V}$ is required for the oxidative decarboxylation of proline derivatives. ${ }^{55}$ However, ruthenium catalyst $\mathbf{4 5}$ with a stronger oxidation potential could still not be used in the reaction. It is only when iridium catalyst $\mathbf{4 6}$, which has in addition also a strong reduction potential, was used that the desired product 43 was finally obtained in $90 \%$ yield. Iridium catalyst $\mathbf{4 7}$, a stronger reductant but weaker oxidant, was not able to promote 
the decarboxylative alkynylation. Under these conditions, the reaction proceeded well, not only with amino acids, but also with $\alpha$-oxo and simple aliphatic carboxylic acids. ${ }^{56}$ The transformation could also be extended to aliphatic and aromatic alkynes. As a testimony of the current intensive research in photoredox catalysis, Xiao and co-workers also published a very similar approach simultaneously with our work. ${ }^{57}$ Further applications combining photoredox catalysis and benziodoxole reagents can be expected in the future.

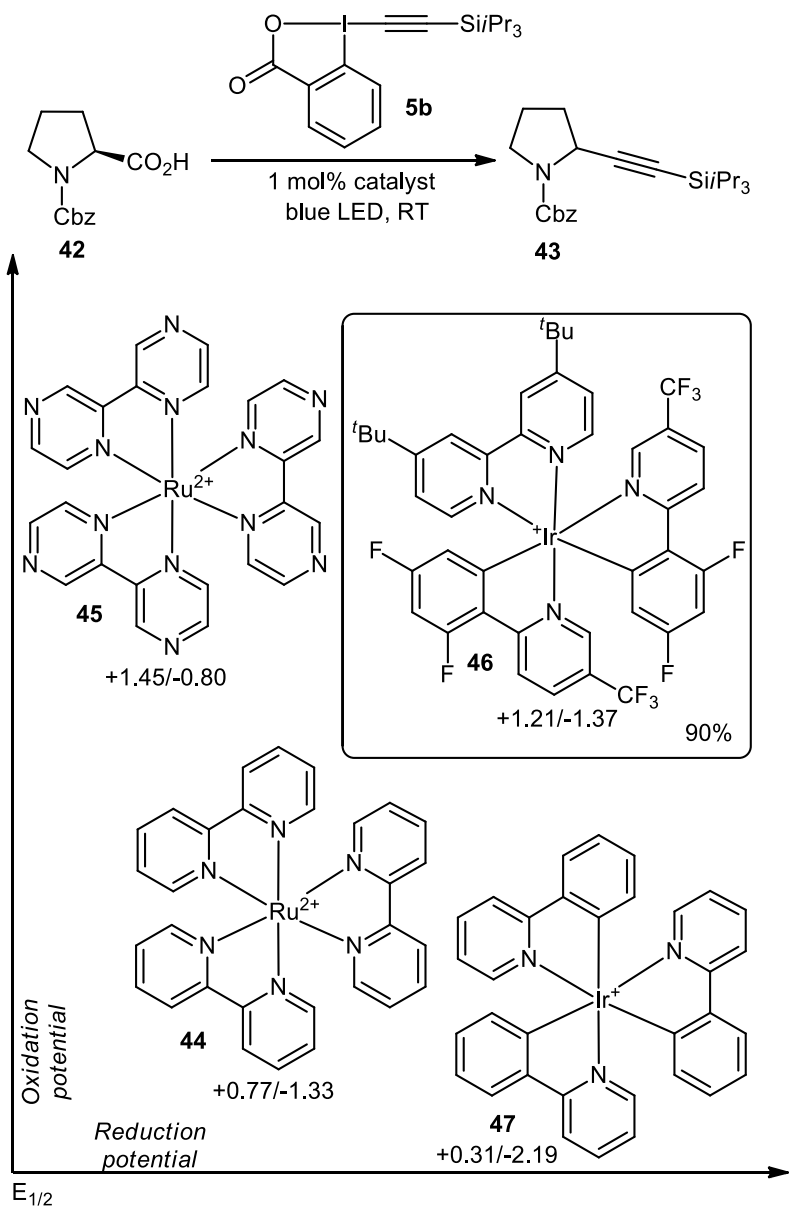

Scheme 11: Decarboxylative alkynylation of protected proline 42.

In 2015, we also started to investigate the reactivity of EBX reagents with carbene intermediates. Recently, numerous multicomponent processes involving carbenes and both nucleophiles and electrophiles have been reported. ${ }^{58}$ Dr. Durga Prasad Hari in our group therefore examined if a three-component reaction could be developed using TIPS-EBX (5b), diazo compound 48 as carbene precursor and benzyl alcohol (49) as nucleophile (Scheme 12, A). When a rhodium catalyst was used, only $\mathrm{O}-\mathrm{H}$ insertion product $\mathbf{5 0}$ was obtained: Apparently, TIPS-EBX (5b) is not electrophilic enough to intercept the formed rhodium ylide intermediate. We then turned to the use of a copper catalyst (Scheme 12, B). Again, the desired three-component product was not obtained. On the other hand, we were able to isolate ester $\mathbf{5 1}$ in $\mathbf{1 0 \%}$ yield, which resulted from the reaction of the 2-iodobenzoate formed from TIPS-EBX (5b) with the carbene intermediate. The formation of this unexpected product was highly interesting, as it allows adressing one of the current limitations of EBX reagents: The formation of benzoic acid derivatives as stoichiometric waste. Optimization of the catalyst, in particular the use of diimine ligand 52, finally led to the formation of the addition product in high yield (Scheme 12, C). ${ }^{59}$ The transformation was very general, allowing variation of both the diazo compound and the EBX reagent and the formation of silyl, alkyl and aryl alkynes. Interestingly, when vinyl diazo compounds were used, only the enyne resulting from conjugated alkynylation was obtained. Currently, our group is working on the development of further reactions involving carbene intermediates and benziodoxole reagents.
A)<smiles>COC(=O)C(=N)c1ccccc1</smiles>

B)<smiles>CC(=O)C(=N)c1ccccc1</smiles>
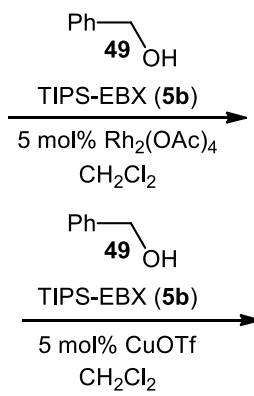

C)

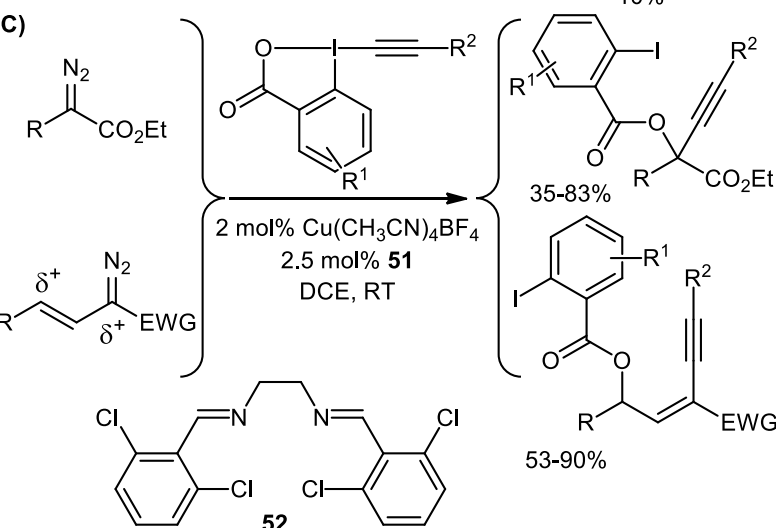

Scheme 12: Discovery of the oxyalkynylation of diazo compounds.

\section{Going beyond synthetic organic chemistry}

The main field of research of our group is synthetic organic chemistry. However, when we developed the thioalkynylation reaction and realized its exceptional rate with sulfur nucleophiles in presence of many other reactive functional groups, we immediately realized that it could have potential for the alkynylation of cysteine under physiological conditions. Lacking expertise in the field of chemical biology, we started a collaboration with the Adibekian group working in chemical proteomics at the University of Geneva. The idea was to use EBX reagents for the functionalization of proteins with reactive cysteines, based on the fact that the thiol is much more acidic in this case and can be deprotonated at physiological $\mathrm{pH}$. Currently, iodoacetamide derivatives are used for this purpose, ${ }^{60}$ but they still present limitations such as low stability, insufficient labelling at low concentration and lack of selectivity. Particularly attractive was the use of benziodoxolone 5i (JW-RF010) first synthesized by Dr. Reto Frei in our group, as the azide group in the alkyl chain allows for easy labelling via [3+2] cycloaddition (Figure $5, \mathbf{A}$ ). In fact, the reactivity of $\mathbf{5 i}$ was higher than iodoacetamide 53, allowing cysteine labeling at lower concentration (Figure 5, B). ${ }^{61}$ It was more selective for cysteine over other amino acids than iodoacetamide $\mathbf{5 3}$ (Figure 
5, C). Most importantly, 866 proteins could be identified, which were not labelled with iodoacetamide 53 (Figure 1, D).

A)<smiles>C#CCNC(=O)CI</smiles>

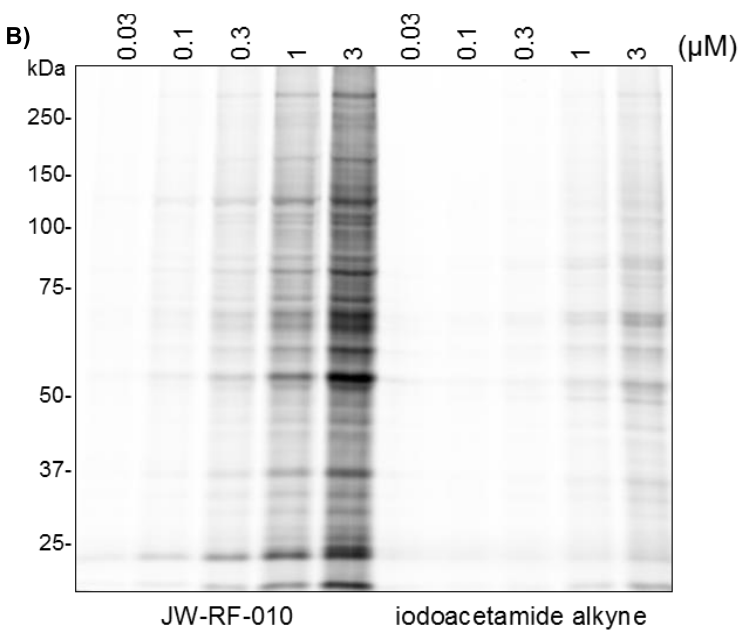

C)

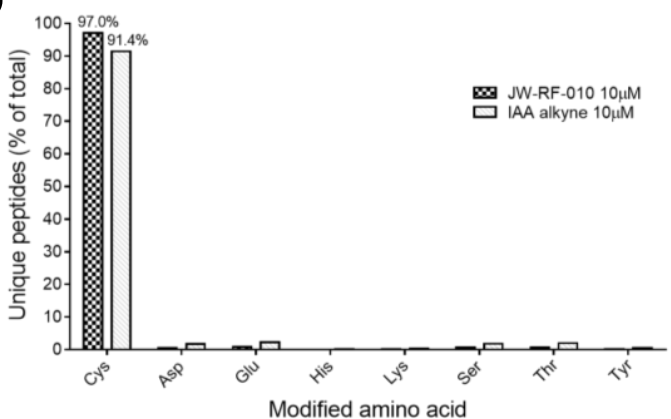

D)

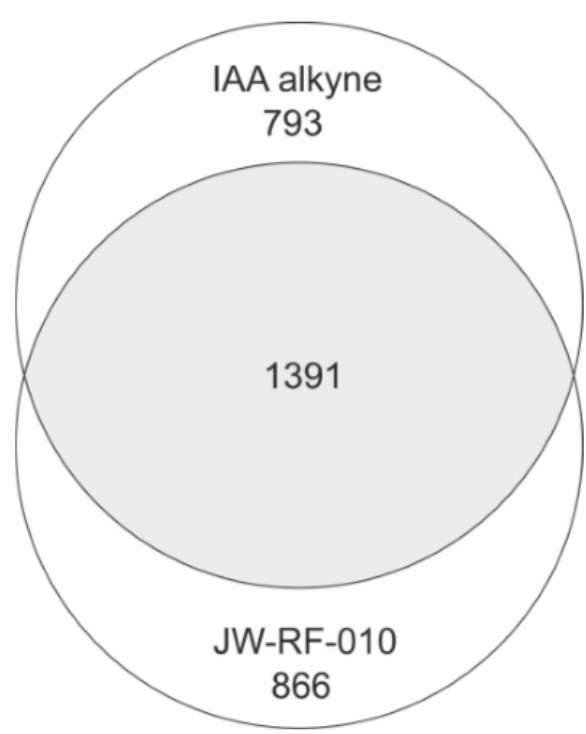

Figure 5: Comparison of JW-RF-010 (5i) and iodoacetamide 53 for the functionalization of proteins: A) Structure of the reagents. B) Comparison of labeling intensity at different concentration. C) Selectivity for cysteine labeling. D) Number of proteins identified.

This allowed identifying caseine kinase $\mathrm{I} \gamma$, a cysteine active kinase and potent oncogene, as a new target of the natural product curcumin. With this proof of principle, a broad potential for EBX reagents as tools for target identification can be expected.

Of course, the thiol group of cysteine is not the only interesting target for applications of the thiol alkynylation reaction. Recently, we worked with the Matile group at the University of Geneva for using JW-RF-010 (5i) as a very efficient terminator for the polymerization of cell-penetrating polysulfides. ${ }^{62}$

\section{Conclusions}

Since my first proposal of expanding the use of electrophilic alkynylation synthons in 2006, I was fortunate to see the idea progress far beyond what I initially considered. The discovery of EBX reagents was certainly associated with a large part of luck, but it made us aware of the tremendous potential of cyclic hypervalent iodine reagents for the transfer of functional groups in non-conventional way. Research in the area is truly bourgeoning now, and new results by no mean limited to trifluoromethylation or alkynylation are regularly reported by research group throughout the world. ${ }^{7 e}$ I am convinced that still many more treasures of reactivity will be found in the future in the "magic box" of hypervalent iodine reagents.

\section{Acknowledgment}

We thank ERC (European Research Council, Starting Grant iTools4MC, number 334840) and EPFL for financial support.

\section{References}

(1) (a) Wirth, T. Hypervalent iodine chemistry: modern developments in organic synthesis. Springer: New York, 2003. (b) Zhdankin, V. V.; Stang, P. J. Chem. Rev. 2008, 108, 5299. (c) Zhdankin, V. V. Hypervalent iodine chemistry: Preparation, structure, and synthetic applications of polyvalent iodine compounds. Wiley, 2014. (d) Yoshimura, A.; Zhdankin, V. V. Chem. Rev. 2016, 116, 3328.

(2) Dess, D. B.; Martin, J. C. J. Org. Chem. 1983, 48, 4155.

(3) Zhdankin, V. V. Curr. Org. Synth. 2005, 2, 121.

(4) (a) Eisenberger, P.; Gischig, S.; Togni, A. Chem. Eur. J. 2006, 12, 2579. (b) Kieltsch, I.; Eisenberger, P.; Togni, A. Angew. Chem., Int. Ed. 2007, 46, 754.

(5) For a review, see: Charpentier, J.; Frueh, N.; Togni, A. Chem. Rev. 2015, 115, 650.

(6) (a) Ochiai, M.; Masaki, Y.; Shiro, M. J. Org. Chem. 1991, 56, 5511. (b) Zhdankin, V. V.; Kuehl, C. J.; Krasutsky, A. P.; Bolz, J. T.; Simonsen, A. J. J. Org. Chem. 1996, 61, 6547.

(7) (a) Brand, J. P.; Fernandez Gonzalez, D.; Nicolai, S.; Waser, J. Chem. Commun. 2011, 47, 102. (b) Brand, J. P.; Waser, J. Chem. Soc. Rev. 2012, 41, 4165. (c) Kaschel, J.; Werz, D. B. Angew. Chem., Int. Ed. 2015, 54, 8876. (d) Waser, J., Alkynylation with Hypervalent Iodine Reagents. In Hypervalent Iodine Chemistry, Wirth, T., Ed. Springer International Publishing: Cham, 2016; pp 187-222. (e) Li, Y.; Hari, D. P.; Vita, M. V.; Waser, J. Angew. Chem., Int. Ed. 2016, $55,4436$.

(8) Diederich, F.; Stang, P. J.; Tykwinski, R. R., Acetylene Chemistry: Chemistry, Biology and Material Science. Wiley-VCH, 2005.

(9) (a) Frantz, D. E.; Fassler, R.; Carreira, E. M. J. Am. Chem. Soc. 2000, 122, 1806. (b) Frantz, D. E.; Fassler, R.; Tomooka, C. S.; Carreira, E. M. Acc. Chem. Res. 2000, 33, 373. (c) Trost, B. M.; Weiss, A. H. Adv. Synth. Catal. 2009, 351, 963.

(10) Zhdankin, V. V.; Stang, P. J. Tetrahedron 1998, 54, 10927.

(11) Beringer, F. M.; Galton, S. A. J. Org. Chem. 1965, 30, 1930.

(12) Selected examples: (a) Ochiai, M.; Kunishima, M.; Nagao, Y.; Fuji, K.; Shiro, M.; Fujita, E. J. Am. Chem. Soc. 1986, 108, 8281. (b) Ochiai, M.; Ito, T.; Takaoka, Y.; Masaki, Y.; Kunishima, M.; Tani, S.; Nagao, Y. J. Chem. Soc., Chem. Commun. 1990, 118. (c) Stang, P. J.; Kitamura, T. J. Am. Chem. Soc. 1987, 109, 7561. (d) Stang, P. J.; Williamson, B. L.; Zhdankin, V. V. J. Am. Chem. Soc. 1991, 113, 5870 . 
(13) The angle between alkyne and phenyl should be $90^{\circ}$ in the alkynyliodonium salt, not $180^{\circ}$ as in the original proposal.

(14) Poulsen, T. B.; Bernardi, L.; Aleman, J.; Overgaard, J.; Jorgensen, K. A. J. Am. Chem. Soc. 2007, 129, 441.

(15) Stang, P. J.; Boehshar, M.; Wingert, H.; Kitamura, T. J. Am. Chem. Soc. 1988, 110, 3272.

(16) Fernandez Gonzalez, D.; Brand, J. P.; Waser, J. Chem. Eur. J. 2010, 16, 9457.

(17) (a) Fernández González, D.; Brand, J. P.; Mondière, R.; Waser, J. Adv. Synth. Catal. 2013, 355, 1631. Maruoka and co-workers were later able to develop an alkynylation with EBX reagents proceeding with more than $90 \%$ ee: (b) Wu, X.; Shirakawa, S.; Maruoka, K. Org. Biomol. Chem. 2014, 12, 5388.

(18) We focused in particular on the activation of aldehydes with prolinol or MacMillan type catalysts. In 2013, Huang and coworkers showed that it was possible to activate aldehydes with amines for $\alpha$-alkynylation with EBX reagents, but only using unsubstituted pyrrolidine as catalyst: Wang, Z.; Li, X.; Huang, Y. Angew. Chem., Int. Ed. 2013, 52, 14219.

(19) Nicolai, S.; Erard, S.; Fernandez Gonzalez, D.; Waser, J. Org. Lett. 2010, 12, 384.

(20) Nicolai, S.; Piemontesi, C.; Waser, J. Angew. Chem., Int. Ed. 2011, 50, 4680.

(21) Brand, J. P.; Siles, J. I. O.; Waser, J. Synlett 2010, 881.

(22) (a) Deprez, N. R.; Kalyani, D.; Krause, A.; Sanford, M. S. J. Am. Chem. Soc. 2006, 128, 4972. (b) Phipps, R. J.; Grimster, N. P.; Gaunt, M. J. J. Am. Chem. Soc. 2008, 130, 8172.

(23) Brand, J. P.; Charpentier, J.; Waser, J. Angew. Chem., Int. Ed. 2009, $48,9346$.

(24) (a) Brand, J. P.; Waser, J. Angew. Chem., Int. Ed. 2010, 49, 7304. (b) Brand, J. P.; Chevalley, C.; Scopelliti, R.; Waser, J. Chem. Eur. J. 2012, 18, 5655. (b) Brand, J. P.; Waser, J. Org. Lett. 2012, 14, 744. (c) Li, Y. F.; Waser, J. Beilstein J. Org. Chem. 2013, 9, 1763.

(25) Brand, J. P.; Waser, J. Synthesis 2012, 44, 1155.

(26) Finkbeiner, P.; Kloeckner, U.; Nachtsheim, B. J. Angew. Chem., Int. Ed. 2015, 54, 4949 .

(27) Ariafard, A. ACS Catalysis 2014, 4, 2896.

(28) (a) Kolb, H. C.; Finn, M. G.; Sharpless, K. B. Angew. Chem., Int. Ed. 2001, 40, 2004. (b) Rostovtsev, V. V.; Green, L. G.; Fokin, V. V.; Sharpless, K. B. Angew. Chem., Int. Ed. 2002, 41, 2596. (c) Tornoe, C. W.; Christensen, C.; Meldal, M. J. Org. Chem. 2002, 67, 3057. (d) Meldal, M.; Tornoe, C. W. Chem. Rev 2008, 108, 2952. (e) Sletten, E. M.; Bertozzi, C. R. Angew. Chem., Int. Ed. 2009, 48, 6974. (f) Thirumurugan, P.; Matosiuk, D.; Jozwiak, K. Chem. Rev. 2013, 113, 4905.

(29) (a) Zhdankin, V. V.; Kuehl, C. J.; Krasutsky, A. P.; Formaneck, M. S.; Bolz, J. T. Tetrahedron Lett. 1994, 35, 9677. (b) Krasutsky, A. P.; Kuehl, C. J.; Zhdankin, V. V. Synlett 1995, 1081. (c) Zhdankin, V. V.; Krasutsky, A. P.; Kuehl, C. J.; Simonsen, A. J.; Woodward, J. K.; Mismash, B.; Bolz, J. T. J. Am. Chem. Soc. 1996, 118, 5192. (d) Akai, S.; Okuno, T.; Egi, M.; Takada, T.; Tohma, H.; Kita, Y. Heterocycles 1996, $42,47$.

(30) Results obtained by Mr. Jonathan Brand and Gergely Tolnai. We ended up publishing these results only in 2016: (a) Tolnai, G. L.; Brand, J. P.; Waser, J. Beilstein J. Org. Chem. 2016, 12, 745. For a similar approach, see: (b) Hansen, M. B.; Hubalek, F.; Skrydstrup, T.; Hoeg-Jensen, T. Chem. Eur. J. 2016, 22, 1572.

(31) Selected examples: (a) Tobisu, M.; Ano, Y.; Chatani, N. Org. Lett. 2009, 11, 3250. (b) Ano, Y.; Tobisu, M.; Chatani, N. J. Am. Chem. Soc. 2011, 133, 12984.

(32) Selected examples: (a) Gong, J.; Fuchs, P. L. J. Am. Chem. Soc. 1996 118, 4486. (b) Schaffner, A.-P.; Darmency, V.; Renaud, P. Angew. Chem., Int. Ed. 2006, 45, 5847.

(33) For selected examples of C-H functionalization with EBX reagents using late metal catalysis, see: (a) Feng, C.; Loh, T.-P. Angew. Chem., Int. Ed. 2014, 53, 2722. (b) Xie, F.; Qi, Z.; Yu, S.; Li, X. J. Am. Chem. Soc. 2014, 136, 4780. (c) Collins, K. D.; Lied, F.; Glorius, F. Chem. Comm. 2014, 50, 4459. For selected examples of radical alkynylation, see: (d) Liu, X.; Wang, Z;; Cheng, X.; Li, C. J. Am. Chem.
Soc. 2012, 134, 14330. (e) Zhang, R.-Y.; Xi, L.-Y.; Zhang, L.; Liang, S.; Chen, S.-Y.; Yu, X.-Q. RSC Advances 2014, 4, 54349. (f) Wang, H.; Guo, L. N.; Wang, S.; Duan, X.-H. Org. Lett. 2015, 17, 3054.

(34) Tolnai, G. L.; Ganss, S.; Brand, J. P.; Waser, J. Org. Lett. 2013, 15, 112.

(35) Brand, J. P.; Chevalley, C.; Waser, J. Beilstein J. Org. Chem. 2011, 7, 565.

(36) Hashmi, A. S. K.; Schwarz, L.; Choi, J-H.; Frost, T. M. Angew. Chem., Int. Ed. 2000, 39, 2285.

(37) Li, Y.; Brand, J. P.; Waser, J. Angew. Chem., Int. Ed. 2013, 52, 6743.

(38) Hashmi, A. S. K.; Yang, W. B.; Rominger, F. Chem. Eur. J. 2012, 18 , 6576.

(39) Li, Y.; Waser, J. Angew. Chem., Int. Ed. 2015, 54, 5438.

(40) Evano, G.; Blanchard, N.; Compain, G.; Coste, A.; Demmer, C. S.; Gati, W.; Guissart, C.; Heimburger, J.; Henry, N.; Jouvin, K.; Karthikeyan, G.; Laouiti, A.; Lecomte, M.; Martin-Mingot, A.; Metayer, B.; Michelet, B.; Nitelet, A.; Theunissen, C.; Thibaudeau, S.; Wang, J. J.; Zarca, M.; Zhang, C. Y. Chem. Lett. 2016, 45, 574.

(41) Selected examples: (a) Stang, P. J.; Zhdankin, V. V. J. Am. Chem. Soc. 1990, 112, 6437. (b) Tykwinski, R. R.; Williamson, B. L.; Fischer, D. R.; Stang, P. J.; Arif, A. M. J. Org. Chem. 1993, 58, 5235. (c) Koumbis, A. E.; Kyzas, C. M.; Savva, A.; Varvoglis, A. Molecules 2005, 10, 1340. (d) Hamnett, D. J.; Moran, W. J. Org. Biomol. Chem. 2014, 12, 4156.

(42) Frei, R.; Waser, J. J. Am. Chem. Soc. 2013, 135, 9620.

(43) Frei, R.; Wodrich, M. D.; Hari, D. P.; Borin, P. A.; Chauvier, C.; Waser, J. J. Am. Chem. Soc. 2014, 136, 16563.

(44) Wodrich, M. D.; Caramenti, P.; Waser, J. Org. Lett. 2016, 18, 60.

(45) (a) Chen, C. C.; Waser, J. Chem. Commun. 2014, 50, 12923. (b) Chen, C. C.; Waser, J. Org. Lett. 2015, 17, 736.

(46) Frei, R.; Courant, T.; Wodrich, M. D.; Waser, J. Chem. Eur. J. 2015, 21, 2662.

(47) Chen, M. S.; White, M. C. Science 2007, 318, 783.

(48) Sharma, A.; Hartwig, J. F. Nature 2015, 517, 600.

(49) Vita, M. V.; Waser, J. Org. Lett. 2013, 15, 3246.

(50) Vita, M. V.; Waser, J. Angew. Chem., Int. Ed. 2015, 54, 5290. We thank Dr. Fides Benfatti and Dr. Tony O'Sullivan from Syngenta Crop Protection Münchwilen AG for providing DSC measurements.

(51) Deng, Q.-H.; Bleith, T.; Wadepohl, H.; Gade, L. H. J. Am. Chem. Soc. 2013, 135, 5356.

(52) (a) Vita, M. V.; Mieville, P.; Waser, J. Org. Lett. 2014, 16, 5768. (b) Vita, M. V.; Caramenti, P.; Waser, J. Org. Lett. 2015, 17, 5832.

(53) Selected examples: (a) Huang, H.; Zhang, G.; Gong, L.; Zhang, S.; Chen, Y. J. Am. Chem. Soc. 2014, 136, 2280. (b) Huang, H.; Zhang, G.; Chen, Y. Angew. Chem., Int. Ed. 2015, 54, 7872.

(54) Selected examples: (a) Chu, L.; Ohta, C.; Zuo, Z;; MacMillan, D. W. C. J. Am. Chem. Soc. 2014, 136, 10886. (b) Noble, A.; MacMillan, D. W. C. J. Am. Chem. Soc. 2014, 136, 11602. (c) Zuo, Z.; Ahneman, D. T.; Chu, L.; Terrett, J. A.; Doyle, A. G.; MacMillan, D. W. C. Science 2014, 345, 437. (d) Zuo, Z.; MacMillan, D. W. C. J. Am. Chem. Soc. 2014, 136, 5257.

(55) Prier, C. K.; Rankic, D. A.; MacMillan, D. W. C. Chem. Rev. 2013, 113,5322

(56) Le Vaillant, F.; Courant, T.; Waser, J. Angew. Chem., Int. Ed. 2015, 54,11200 .

(57) Zhou, Q.-Q.; Guo, W.; Ding, W.; Wu, X.; Chen, X.; Lu, L.-Q.; Xiao, W.-J. Angew. Chem., Int. Ed. 2015, 54, 11196.

(58) (a) Guo, X.; Hu, W. Acc. Chem. Res. 2013, 46, 2427. (b) Xia, Y.; Feng, S.; Liu, Z.; Zhang, Y.; Wang, J. Angew. Chem., Int. Ed. 2015, 54, 7891.

(59) Hari, D. P.; Waser, J. J. Am. Chem. Soc. 2016, 138, 2190.

(60) (a) Weerapana, E.; Wang, C.; Simon, G. M.; Richter, F.; Khare, S.; Dillon, M. B. D.; Bachovchin, D. A.; Mowen, K.; Baker, D.; Cravatt, B. F. Nature 2010, 468, 790. (b) Shannon, D. A.; Weerapana, E. Curr. Opin. Chem. Biol. 2015, 24, 18.

(61) Abegg, D.; Frei, R.; Cerato, L.; Prasad Hari, D.; Wang, C.; Waser, J.; Adibekian, A. Angew. Chem., Int. Ed. 2015, 54, 10852. Figure 5, BD were adapted with permission from this publication. Copyright 2015, John Wiley and Sons. 
(62) Morelli, P.; Martin-Benlloch, X.; Tessier, R.; Waser, J.; Sakai, N.; Matile, S. Polym. Chem. 2016, 7, 3465.

\section{Biosketches}

Jérôme Waser was born in Sierre, Valais, Switzerland in 1977. He obtained is chemistry Diploma at ETH
Zurich in 2001. From 2002 to 2006, he was a PhD student at ETH Zurich with Prof. Erick M. Carreira. He
then joined Prof. Barry M. Trost at Stanford University as a SNF postdoctoral fellow. From 2007 to 2014,
he was an assistant professor at EPF Lausanne (EPFL). Since June 2014, he has been associate professor
at EPFL. He is a recipient of the ERC Starting Grant 2013, the Werner prize of the Swiss Chemical Society
2014 and the Springer Heterocyclic Chemistry Award 2016.

